\title{
Innovation and competitive factors of non-R\&D industrial enterprises. The case of north-eastern Poland
}

\author{
Robert Ciborowski \\ Economics and Management Faculty, \\ University of Bialystok, \\ Bialystok, Poland \\ Email: r.ciborowski@uwb.edu.pl
}

\begin{abstract}
This paper investigates the drivers of technology and innovation in Podlaskie (north-eastern Poland). There are reasons to believe that the convergence of Podlaskie's technology development to the levels of the rest of Poland will continue, but will proceed more slowly. The paper concludes that technology transfer and R\&D investment have sped along at a spectacular pace in Poland in the recent years, although innovation in modern sectors lags somewhat behind. R\&D activities have become the most substantial factor of innovation research in the attempt to explain the phenomena of innovation ability and competitiveness. There is a lot of empirical literature that shows the importance of firm-internal $\mathrm{R} \& \mathrm{D}$ activities as the main source of productivity, technological innovations to improve competitiveness, especially in fast growing high-tech industries. What seems to be the basic problem is the impact of economic changes on R\&D activity and technology transfer.
\end{abstract}

Keywords: R\&D; technology transfer; institutional settings; competitiveness; Poland.

Reference to this paper should be made as follows: Ciborowski, R. (2016) 'Innovation and competitive factors of non-R\&D industrial enterprises. The case of north-eastern Poland', Int. J. Transitions and Innovation Systems, Vol. 5, No. 1, pp.66-79.

Biographical notes: Robert Ciborowski is a Lecturer of Economics and Innovation Strategy at the University of Bialystok. He has worked for public and private sector in diverse fields of science, technology and development. $\mathrm{He}$ held several responsible positions in the university and published over 40 papers and articles. He is a member of EASST and PTE.

\section{Introduction}

Economic changes in Poland created a totally new situation for Polish enterprises as they became exposed to free trade, multinational investment flows, various opportunities to cooperate with foreign companies and to conduct $\mathrm{R} \& \mathrm{D}$ activity. A restructuring of the institutional settings is extremely important for the Polish economy in the course of transition. The transition process has, in turn, revolutionised the understanding of the innovation process. However, transition has failed to revolutionise the structures of S\&T in Poland. 
Comparative studies indicate that innovation activity in Poland is, in general, significantly below that of the EU, and in the north-east it is even lower than in the other parts of Poland. North-eastern Poland is a peripheral region with traditional structure of production and employment. It remains one of the less innovative regions of Poland and the enlarged EU. This is probably a result of the weakness of our industrial enterprises, which do not meet the requirements of modern international competitiveness. It is a heritage of past times, when the creation of innovation systems was not considered a priority factor of economic development. Additionally, north-eastern Poland is still undergoing intensive modernisation of its techno-logical capabilities. The capital and production structure are extremely outdated and fail to meet the demands of the international trade competition, and above all non-price competition.

It seems, therefore, that creating conditions for a learning economy approach might become a crucial factor determining the nature and dynamics of development processes as well as influencing the region's future innovation capabilities. Construction of a new regional innovation structure and transfer of technologies should support modernisation processes in companies and enhance the development opportunities of the national economy as a whole, but especially in peripheral regions (Lundvall, 2010; Edquist, 1997). Those processes will accelerate the technological convergence of regions and give a much needed spur to the open economy.

Acceleration in the rate of change implies that knowledge and skills are more exposed to rapid moral depreciation. Therefore, the increase in the stock of knowledge may be less dramatic than it appears. An alternative hypothesis is that we are moving into a learning economy, where the success of individuals, firms, regions and countries will depend primarily on their ability to learn. The speeding up of change reflects the rapid diffusion of information technology, the widening of the global marketplace, with the inclusion of new strong competitors, and deregulation of and less stability in markets in terms of open economy (Drucker, 1999; Lundvall, 2000; Archibugi and Lundvall, 2001).

In this context, learning is defined as a process whose core is the acquisition of competence and skills that allow the learning individual to be more successful in reaching individual goals or those of his/her organisation. It will also involve a change in context of meaning and purpose for the individual and affect his/her existing knowledge.

Many empirical studies show that a significant number of firms do not invest in their own R\&D. Innovation ability is based on firm-specific routines and individual improvement. Enterprises show considerable heterogeneity in their innovation behaviour and strategies, even within similar framework conditions of sectors or innovation systems (Srholec and Verspagen, 2008).

The paper aims to show a relationship between R\&D and the competitiveness of firms in the traditional sectors of the economy in north-eastern Poland (Podlaskie region). The innovativeness and economic activity of these firms do not depend simply on high technology or R\&D expenditures in the conditions of an open economy.

\section{Innovation as a factor of regional development}

Innovation lowers the cost and time of communication, shortens the distance between people and societies, contributing in this way to creating a global information network. This creates a new quality since information becomes a productive factor of production, along with capital, labour, land, and other factors determining economic growth in open 
economies. Thanks to the diffusion of innovation, there is equality between the technological capacities of companies located in different countries, thus the technological parity increases. The same tendency exists on the level of countries and is described as the convergence of technology. In the process of innovation diffusion, the key role is played by transnational corporations, through geographical integration of the diffused functions/operations of the scientific and developmental nature, and their contribution to the global strategy of their national economies. In spite of the presence of the above mentioned phenomena, the world's innovation potential is strongly varied dimensionally.

Innovation in small and poorly developed regions should be analysed in terms of an open economy. An open economy enables its participants to absorb foreign knowledge through international trade, which frequently plays a more important role for domestic innovation and growth than investment in domestic R\&D.

The model of an open economy assumes the conditions of full diffusion of technological advancement and capital mobility. As a result, long-term market growth rates should be the same across economies and reaching the steady state should be automatic and instantaneous. This is not the case in reality as capital and technology flows do not happen automatically, but are affected by a number of restricting factors. Therefore, the easier the flow of capital and technology, the higher the market growth rate because the inflow of capital raises savings rates, while knowledge diffusion enhances technological progress. The influence of these two factors on growth dynamics is equal since they are substitutive and complementary with each other [Barro and Sala-i-Martin, (1995), p.281]. In the short term, knowledge diffusion works in the same way as capital inflow, while, at the same time, technological potential determines the in-flow of capital investment, which guarantees an internal rate of return above the rate of return in the investing country (a reverse situation is also possible, although less likely).

Differences in technological levels, therefore, have a bearing on the rate of GDP. The greater these differences, the faster the growth becomes. The closer the technology frontier, the more complex the technologies and the higher the cost of their transfer, which slows down diffusion. Absorption of technology depends on the absorption capabilities determined by: R\&D expenditure, education, qualifications (innovation and economic policy, the quality and flexibility of the market), propensity for innovation, institutional infrastructure, and the degree of economic openness (Nelson and Winter, 1982). Another important factor is the ability to cover the costs of absorption and to use it efficiently for economic development.

There are two factors that will affect a firm's incentives to learn, and to invest in absorptive capacity via its R\&D expenditures. First, there is the quantity of knowledge to be assimilated and exploited. Second, there is the difficulty in learning. The cost of its absorption may vary depending on the characteristic of the knowledge [Cohen and Levinthal, (1990), pp.139-140].

This resembles Schumpeter's approach, where innovation is treated as all technological and organisational change aimed at achieving a new better state of affairs. A factor that is crucial for its success is the size of R\&D expenditure, i.e. capacity for innovative solutions, while the number of implementations and the level of total factor productivity (TFP) are a reflection of their results.

Technological advancement sparked off this type of transformation, which accelerated along with the progressing liberalisation of the world economy. Lower costs of transport and communication, accompanied by more liberal trade and elimination of 
financial constraints result in a greater flow of goods, services and capital across economies, which is best reflected in the flow of direct foreign investment. All economies have become more open than only 20 years ago. Moreover, fiercer competition has boosted innovativeness (Berger and Dore, 1996; Friedman, 2001).

There has been a decline in the importance of cheap labour as a source of comparative advantages. Differences in wages across countries have until recently been a factor of major influence on location of businesses. This used to benefit countries that specialised in traditional labour-absorbing industries. In the 1980s, highly developed countries increasingly started to use automated technologies in traditional industries (clothes and textile industry, shoe industry, iron and steel industry, electronic assembly industry and car industry). As a result, these branches are becoming technology- and capital-intensive. This helps them develop and thrive even in countries with high labour costs. Under such circumstances, advanced technologies are becoming a substitute for cheap labour offered by developing countries.

Thanks to technology diffusion, an equalisation of technological capabilities is taking place in enterprises across countries and, thus, an increase in technological parity can be observed. A similar tendency, labelled as technological convergence, is visible on the national level. In the process of technology diffusion, a key role is played by transnational corporations and cooperation, thanks to geographical integration of dispersed R\&D functions/operations and a subordination of these functions to the global strategies of their mother companies.

It is crucial, therefore, to define the stability of regulatory systems and national institutions in the circumstances of growing competition [Boyer and Drache, (1996), pp.48-50]. It also seems worthwhile to address the question of whether institutional differences between economies are large enough to prevent deregulation processes and international integration from creating a single, uniform economic model.

The role of institutional factors has changed in the last few decades due to a greater role of the market and increased competition, as well as a more limited role of the government in economic processes. In individual OECD countries, this process happened with various intensity, which was reflected in the changes in the structure of property, the role of the market in allocation decisions, as well as in the degree of entrepreneurship. These factors variously influenced entire economic systems [Nicoletti and Scarpetta, (2003), pp.5-6].

Enterprises do not have internal information systems which would acquaint investors with development directions and with the state of their progress. The only available parameter is data from accountancy reports, which cover only short periods of time. New enterprises, meanwhile, particularly in high-tech branches, use venture capital since they focus on profit maximisation over a long period of time [Hall and Franzese, (1998), p.509].

The institutional system of the job market allows enterprises to cut operational costs through limiting employment and is complementary to the financial market, which makes it possible to use financial funds provided when profits are achieved. Comprehensive education, in turn, is complementary to a flexible job market, which enables technology transfer and high factor mobility. Such a system of dependencies guarantees high efficiency of cooperation in the fields of R\&D and technology transfer.

In order to specify the structural and institutional conditions for the creation of innovation systems, it is necessary to conduct an in-depth analysis of national and regional innovation systems. A comparison of these systems in highly developed 
countries helps to establish the structure and significance of institutional segments, which include:

- companies and their innovation capacities, including their vertical relationships with suppliers and customers

- universities, and public research and development laboratories with their ability to create general knowledge, realising the educational mission, and catering for the demands of the business sector

- economic policies oriented towards educating the labour force, creating pro-development climate in the macroeconomic financial and trading system, and strengthening trust in financial institutions and the rule of law.

The dynamics of this system can be explained by the growing role of science and R\&D in the economy: the so-called 'science push effect'. Higher education is a factor which integrates the educational and universal capacities of science, leading to economic growth, mainly through social and institutional change. The structure of the components and factors of an innovation system can assume the form of technical infrastructure comprised of:

- competitive and cooperative capabilities of enterprises: in both horizontal and vertical configurations (including R\&D, distribution and purchasers), as well as in regional, national and international configurations

- academic and public research and development laboratories which have opportunities to cooperate with foreign academic institutions, national and local political spheres, as well as with the industrial sector and other social institutions

- the government with its (internal and foreign) scientific, educational, and social policies aimed at improving competitiveness, being a direct consequence of the functioning of the economy and controlled by public institutions.

Every enterprise is a collection of so-called routines: rules, not always formal, which have been adopted to streamline production processes. Innovation, meanwhile, is a sequential process, based on the application of abstract knowledge. Innovation systems, which possess significant capacities to evolve, enable the creation of a complex system for transforming knowledge: from the moment it comes into being to the moment it is applied in the broadest possible way.

The nature of the processes of R\&D application on a regional level is such that they should undergo evolutionary, and not revolutionary, changes. Besides, these changes should be associated with market processes, focused on the creation and application of knowledge.

Nowadays, R\&D activity functions in an open innovation model. Open innovation is a paradigm which assumes that firms can and should use both external and internal ideas, as well as both internal and external paths to market, in their attempts to advance technologically [Chesbrough, (2005), pp.5-6].

In an open model of innovation, new technologies (or ideas for new technologies) that are not interesting for an enterprise might be used outside this enterprise. In such cases, the employers of the organisation often provide a vehicle for innovation, as they might 
resolve to establish their own company on the basis of the new technology. They can sometimes count on the mother company to participate in their efforts, as well as on some support from external organisations. The new firm can also seek financial aid from various other sources [Chesbrough et al., (2015), pp.47-49].

The evolutionary approach to innovation systems helps explain numerous processes that take place inside them, e.g. the creation of knowledge in enterprises, knowledge transfer, or the dynamics of change in human capital.

Innovation is limited by the amount of accessible scientific and technological knowledge, decreasing due to falling revenue from $\mathrm{R} \& \mathrm{D}$. Therefore, innovators are facing important decisions concerning [Coombs et al., (1987), p.108]:

- reduction of production costs

- increasing the complexity of innovation processes

- choosing which innovation projects can be implemented within the limits of accessible knowledge.

This means that the cost of production factors is not always the only consideration when it comes to selecting an innovation strategy. A similar approach is proposed by Binswanger, who distinguishes three innovation factors: profits from innovation, costs of innovation, and the limits of technical possibilities. He describes a positive relationship between the volume of production and the level of R\&D expenditure, pointing out the dependence among current prices of production factors, R\&D structure (labour-saving or capital-saving) and the change in time of the innovation curve [Binswanger, (1974), pp.953-956]. Because he treats $R \& D$ expenditure as a normal investment, research projects are dependent on production factors, re-search productivity and expected costs. A selection process based on these criteria determines the direction and dynamics of innovation.

The approaches within the R\&D paradigm, particularly those focusing on the processual dimension of resource generation and modification, are closely related to the evolutionary perspective. They explicitly recognise the differences and heterogeneity of resource endowments across firms and their individual, socially embedded heuristics of how they generate, combine, deploy, and modify their stock of resources to achieve competitive advantages [Foss et al., (1995), p.3].

The relational-based view, which expands the potential sources of competitive advantage primarily to external sources, and thus has to deal with issues of transaction cost, remains compatible in its basic assumptions.

As this study explores the heterogeneity of innovation patterns in non-R\&Dperforming firms, integrating different approaches allows this very question to be taken into account, as the analytical framework is not narrowed down to either only the firminternal or external dimension, or exclusively limited to only one specific type of innovation input. The approaches broaden the range of what could serve as a firm's competitive advantage far beyond the issue of mere R\&D, by explicitly emphasising heterogeneity (i.e. specificity, individuality, non-imitability) of innovation resources and thus fitting into the previous argumentation based on evolutionary theory. 
Table 1 Overview of resource-based approaches within strategic management

\begin{tabular}{|c|c|c|c|}
\hline & Resource-based theory & Relational-based view & Knowledge-based view \\
\hline Unit of analysis & The firm & $\begin{array}{l}\text { Pair, groups or } \\
\text { networks of firms }\end{array}$ & $\begin{array}{l}\text { Firms and } \\
\text { organisations } \\
\text { as social entities }\end{array}$ \\
\hline $\begin{array}{l}\text { Primary sources of } \\
\text { above-normal } \\
\text { rent/competitive } \\
\text { advantage }\end{array}$ & $\begin{array}{l}\text { Rare, valuable } \\
\text { - } \quad \text { Physical, } \\
\text { technological or } \\
\text { financial resources } \\
\text { - Human resources } \\
\text { - Individual and } \\
\text { organisational } \\
\text { competences } \\
\text { - } \quad \text { Routines, repetitive } \\
\text { patterns of behaviour } \\
\text { and processes } \\
\text { - } \quad \text { Ability to renew } \\
\text { and modify the } \\
\text { resource base through } \\
\text { dynamic capabilities }\end{array}$ & $\begin{array}{l}\text { Relation-specific } \\
\text { investments } \\
\text { - Routines for } \\
\text { inter-firm } \\
\text { knowledge } \\
\text { exchange } \\
\text { - Complementary } \\
\text { resource } \\
\text { endowments } \\
\text { - Effective } \\
\text { mechanisms of } \\
\text { governance }\end{array}$ & $\begin{array}{l}\text { Stock of implicit } \\
\text { knowledge which is } \\
\text { generated through } \\
\text { individual experience } \\
\text { and held by individuals } \\
\text { or the whole } \\
\text { organisation } \\
\text { - Ability of the } \\
\text { firm to renew and } \\
\text { modify the stock of } \\
\text { knowledge through } \\
\text { processes of } \\
\text { learning } \\
\text { - (Stock of explicit } \\
\text { knowledge) }\end{array}$ \\
\hline \multirow{5}{*}{$\begin{array}{l}\text { Isolating } \\
\text { mechanisms }\end{array}$} & \multirow{5}{*}{$\begin{array}{l}\text { Idiosyncrasy } \\
\text { - Causal ambiguity } \\
\text { - Immobility } \\
\text { - Inimitability }\end{array}$} & \multirow{3}{*}{$\begin{array}{l}\text { Causal ambiguity } \\
\text { Interdependencies } \\
\text { Complementarities of } \\
\text { inter-organisational } \\
\text { assets }\end{array}$} & Causal ambiguity \\
\hline & & & Inimitability \\
\hline & & & $\begin{array}{l}\text { Context dependency } \\
\text { Social embeddedness }\end{array}$ \\
\hline & & $\begin{array}{l}\text { Scarce choice of } \\
\text { adequate partners }\end{array}$ & \\
\hline & & $\begin{array}{l}\text { Indivisibility of } \\
\text { common resources }\end{array}$ & \\
\hline \multirow[t]{2}{*}{$\begin{array}{l}\text { Ownership/control } \\
\text { of valuable } \\
\text { resource }\end{array}$} & \multirow[t]{2}{*}{ Individual firms } & \multirow[t]{2}{*}{ Collaborating partners } & $\begin{array}{l}\text { Individuals (implicit } \\
\text { and explicit } \\
\text { knowledge) }\end{array}$ \\
\hline & & & $\begin{array}{l}\text { Firm (shared explicit } \\
\text { and implicit } \\
\text { knowledge) }\end{array}$ \\
\hline $\begin{array}{l}\text { Origin of valuable } \\
\text { resources }\end{array}$ & Internal & External & Internal (external) \\
\hline
\end{tabular}

Source: Som (2012, p.215)

\section{Determinant factors of innovation and competitive potential of Podlaskie Voivodeship}

Non-R\&D companies have limited opportunities for international cooperation that would en-able them to raise their technological level and to increase their competitive capacity. This is due to insufficient capital and human resources as well as a lack of experience in competing on foreign markets [Nowiński and Rialp, (2012), p.221]. 
In recent years, innovation indicators of Podlaskie region were highly variable but the majority of them have improved. The greatest improvement was noted in R\&D expenditure per one inhabitant. In 2010, the indicator stood at just PLN 62 per inhabitant, while in 2014, it reached PLN 68.4, which meant an over 10\% rise, still, however, leaving Podlaskie in the 15 th position out of the 17 Polish provinces. In Podlaskie, only 22 entities conduct research and development activity. This is a very low number. In Mazowieckie (the national leader), there are 16 times as many such institutions (BDL, 2015).

The enterprise sector has the largest share in Poland's R\&D spending structure. In Podlaskie, meanwhile, it is the higher education sector which occupies the leading position in this field, providing employment to nearly $90 \%$ of those involved in research and development in the voivodeship.

As far as Podlaskie's service sector companies are concerned, the expenditure on innovation per inhabitant is PLN 9. In the industrial sector, this figure amounts to PLN 245. In terms of innovation expenditure in industrial enterprises, Podlaskie is ranked in the 12th place. The province is ranked in a fairly high 7 th spot in the category of net income from the sales of innovation products in the private sector. Here, a $23 \%$ rise has been reported, reaching an $11 \%$ share in net income.

Figure 1 R\&D expenditures as a \% GDP (2013, \%) (see online version for colours)

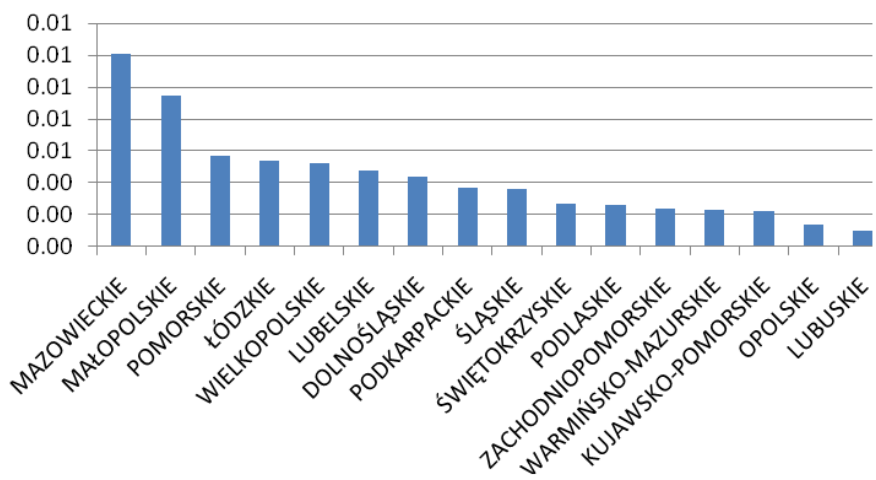

Source: BDL (2015)

Enterprises can be divided into those whose commitment to innovation is manifested in new or improved products, new or significantly improved products, or new or significantly improved processes. The domestic average percentage of innovative companies is $12.57 \%$ of the firms in the service sector, and $18.10 \%$ in the industrial sector. In Podlaskie, the number of industrial sector companies equals $80 \%$ of the national average. As regards the service sector firms, the situation is even worse since they account for just $16 \%$ of the national average.

In Podlaskie Voivodeship, $19 \%$ of industrial enterprises introduce innovative products or processes. This respectable figure ranks the province as high as 6th in Poland. Most frequently, innovation is used for new or significantly improved products, or new or significantly improved processes. In the ranking of service sector firms, Podlaskie occupies 12 th place, with $10 \%$ of innovative companies. Innovation usually occurs in new or significantly improved processes. 
Similarly to other Polish provinces, Podlaskie's companies make sparse use of either domestic or foreign scientific and technological solutions. On the national scale, in 2013 firms were slightly more willing to purchase new technologies from domestic partners. One exception being the production automation systems, which tended to be purchased abroad. A similar trend could be observed in Podlaskie. Apart from the systems for production automation, the region's firms frequently resorted to 'other' types of technology transfer from foreign countries.

Only medium-sized companies of Podlaskie received financial aid from the state budget. Foreign financing for innovation was a rare occurrence in the voivodeship: only $0.01 \%$ of the expenditure. This is analogous to capital investments overall. The above data reflect the poor financial condition of Podlaskie's business companies, and the virtual absence of foreign capital in the region.

Although the number of firms conducting R\&D activity is relatively low, it should be considered a positive tendency that their level (though only claimed) of innovation is higher than the national average. Data confirm the popular opinion that small and medium enterprises have poor innovation performance, as opposed to large firms. In Podlaskie, innovation was implemented by $11 \%$ of the small firms, $31.2 \%$ of the medium-sized ones, and $57.8 \%$ of the large ones (BDL, 2015).

Podlaskie's companies only to a limited extent take advantage of the region's transboundary location and the resultant cooperation opportunities. Enterprises which sign agreements on cooperation for innovative activity create technological development prospects, and largely contribute to the growth potential of their region, its competitive position, and the evolution of consumer goods markets.

Together, R\&D, technology transfer and cooperation for innovation, make up a set of factors which determine innovation performance. Moreover, the transfer of technology and cooperation for innovation can be, in a sense, considered substitutes for R\&D. This means that research and development activity is not always necessary for innovation. Those responsible for the innovation policy of a country or region should bear this in mind, given the low involvement in R\&D of the firms in Podlaskie. In comparison to own research and development initiatives, the transfer of technology and cooperation for innovation might prove a less costly option of obtaining new technological solutions.

A large proportion of the innovating firms in Podlaskie neither purchase technologies nor established cooperation for innovation, nor undertake R\&D activity. This might mean that many of the new or improved products and processes launched by Polish firms do not include any elements of technological innovation. Acquisition of elements or complete new technological solutions is also a time-saving strategy. The saved time could be used for streamlining the existing technologies rather than for attempting to catch-up with the current technological frontier, basing only on the firms' own resources.

The region would benefit greatly if its firms could overcome this introverted tendency. More involvement in technology transfer and cooperation for innovation (especially with foreign firms and R\&D centres in Poland and abroad) should be strongly supported by the creators of the regional innovation policies since it can help to enhance the innovation level of Podlaskie's companies, thus accelerating the development rate of the region. 
Similarly to other Polish provinces, cheap labour force is Podlaskie's main competitive factor [Michalski, (2014), pp.62-63], which results from lack of accessible capital. The key enterprises of the regional economy operate in low and medium-technology sectors.

A shortage of highly-qualified labour, administrative constraints, dearth of capital, limited start-up activity, and inadequate protection of intellectual property are among the most frequently mentioned weaknesses of the innovation systems of the central and eastern European countries [Malo, (2009), p.486]. The north-east of Poland is faced with similar difficulties.

Improvement of Podlaskie's low innovation capability requires considerable and dynamic import of complete technologies, not higher R\&D expenditures. There is a need for future expenditure growth in order to purchase elements of the innovation process such as intangible investments. This is particularly important for non-price competitiveness, which is a multi-dimensional category including quality, reliability, technical specification, design, value creation, service and after-sales support, marketing support and distribution networks, etc.

The largest proportion of Podlaskie's firms consists of non-R\&D ones, so they need more technological capabilities which allows them to conduct their own R\&D activities. Non-R\&D firms need technologies which could be transferred from elsewhere in Poland or from abroad. The potential effect of technology transfer on future innovation capabilities is presented in Table 2 .

In the period 2010-2014, the situation of Podlaskie was alarming. The percentage of firms involved in inward technology transfer was even lower than the national average and engagement in outward TT was almost non-existent - only two firms sold new technologies in the form of means of automation of production processes. Moreover, Polish firms' interest in technology transfer in the past decade was generally falling.

It can also be seen in Table 2 that Podlaskie's enterprises are oriented towards inward rather than outward technology transfer. It is understandable in view of the low innovation and R\&D potential of Polish firms. Enterprises in transition economies will probably need a boost of overseas technologies before they can truly innovate themselves and sell new technologies both to national counterparts and abroad.

Taking into account the possible assumption that more far-reaching, radical innovations are favoured by external relations to partners from the science system, whereas incremental innovations are more likely to be influenced by partners from the same system, i.e. business sector, weak cooperation between Polish enterprises and research organisations is worrying. Interaction with science stimulates firms' innovativeness, because it constitutes a far more diversified range of knowledge sources accessible to enterprises than in the case of intra-business interaction (Kaufmann and Todtling, (2001), pp.791-804].

Together, R\&D, technology transfer and innovation cooperation comprise the set of innovation determinants. Furthermore, technology transfer and innovation cooperation (or networking) can, to some extent, be considered substitutes of R\&D activity. This notion is interesting from the point of view of low involvement in costly R\&D activity on the part of Polish firms. 
Table 2 Technology transfer in industry (non-R\&D firms) in Podlaskie (2010-2014)

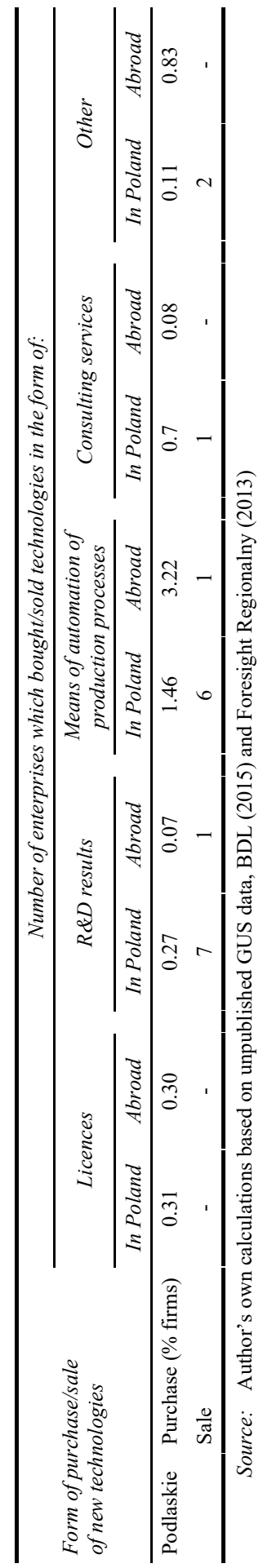


Figure 2 is a presentation of the involvement Podlaskie's firms in the above-mentioned types of R\&D activities compared with the firms' innovativeness, and is designed to help to test the hypothesis that technology transfer and innovation cooperation are innovation determinants and can be regarded as substitutes for R\&D.

Figure 2 Firms innovativeness in Podlaskie versus their engagement in R\&D (2010-2014)

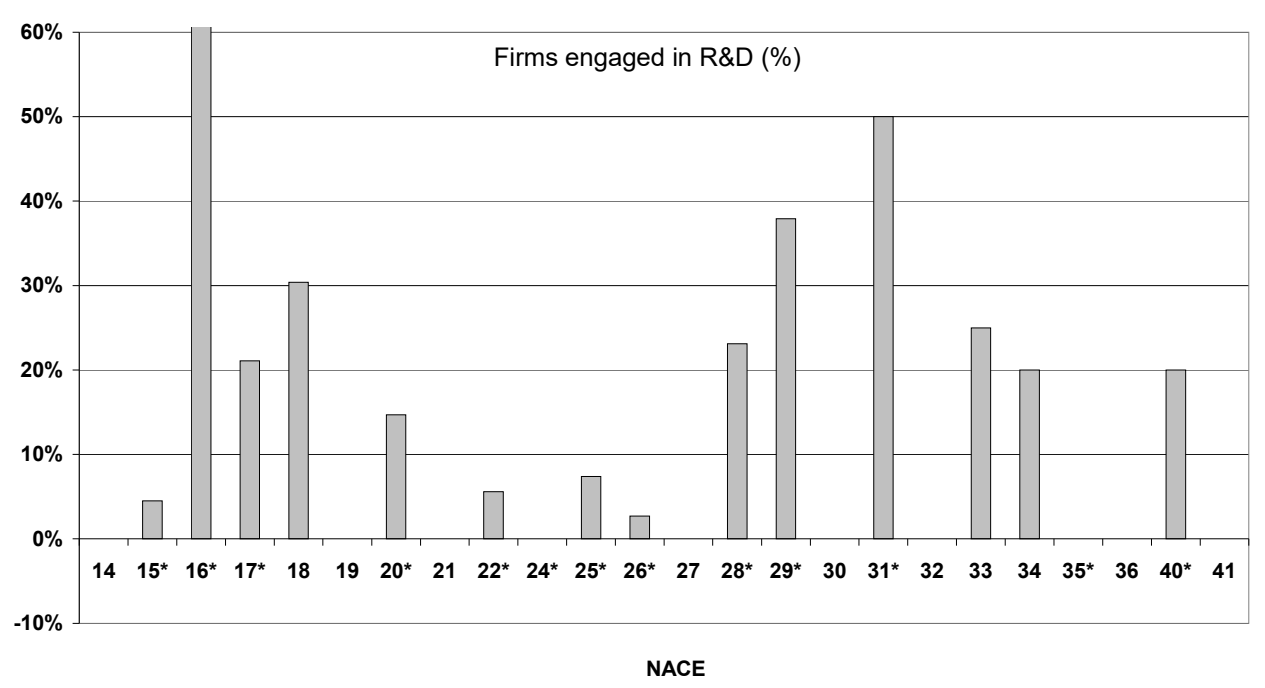

Source: Own calculations based on GUS unpublished data and BDL

The conclusions are as follows:

- in four of the NACE activities with the highest share of innovative firms', involvement in R\&D activity (regarded as a determinant of innovation) was recorded

- $\quad$ in 12 of the NACE activities, the proportion of innovative firms was considerably higher than their engagement in R\&D - in all those activities, firms' involvement in either TT or innovation cooperation or both was recorded

- in the case of six NACE activities where no innovative firms were present, no R\&D, TT or innovation cooperation was recorded

- the most R\&D firms operate in low-tech branches

- the most predominant form of innovation activity is TT

- there is only one industrial activity (NACE 21) with innovative firms and no engagement in either R\&D, TT or innovation cooperation.

The above conclusions seem to suggest that technology transfer is the main opportunity to increase innovation in Podlaskie. Firms should create numerous channels to obtain technologies and after that they should seek possibilities to become innovative. They do need more R\&D, but the adoption of external technologies should happen first. 


\section{Conclusions}

Improvement of Podlaskie's low innovation and competitive capability requires considerable and dynamic imports of new technologies. That is why inward technology transfer should be viewed as a crucial factor influencing Podlaskie's future innovation capability. Additionally, innovations, and particularly radical ones, often depend on a firm's ability to draw on diverse sources of information and knowledge as well as to collaborate on the development of new or improved products and/or processes. For this reason, cooperation for innovation is also very important.

Together, R\&D, technology transfer and innovation cooperation comprise a set of innovation determinants. Furthermore, technology transfer and innovation cooperation (or networking) can, to some extent, be considered substitutes of R\&D activity. Analysis of the data on the regional level allows one to conclude that NACE activities with the highest share of innovative firms recorded involvement of firms in all the three types of activities regarded as innovation determinants. Also the NACE activities where the proportion of innovative firms was considerably higher than their engagement in $R \& D$, marked firms' involvement in either TT, or innovation cooperation, or both.

The ability to create and absorb innovation is an indicator of competitive capability in terms of technological convergence. Greater innovation of Podlaskie is indispensable for narrowing the development gap. Thus, it is of tremendous importance that R\&D expenditure is in-creased, the educational system is streamlined, and that institutional infrastructure supporting innovation and technology transfer is developed. Failure to make adjustments of intra-branch specialisation (based on the technology factor and innovation) and remaining limited to the traditional inter-branch exchange (based on the comparative advantages of labour- and re-sources-intensive products) can hamper the pace of Podlaskie's catch-up, as is observable in the last years of the 1990s and at the beginning of the 21 st century.

\section{References}

Archibugi, D. and Lundvall, B.A. (2001) The Globalizing Learning Economy, University Press (UP), Oxford.

Barro, R.J. and Sala-i-Martin, X. (1995) Economic Growth, McGraw and Hill, New York.

BDL (2015) [online] http://www.stat.gov.pl.

Berger, S. and Dore, R. (1996) National Diversity and Global Capitalism, Cornell University Press, New York.

Binswanger, H.B. (1974) 'A microeconomic approach to induced innovation', Economic Journal, Vol. 84, No. 336, pp.940-958.

Boyer, R. and Drache, D. (1996) States Against Markets, Routledge, New York.

Chesbrough, H. (2005) Open innovation. The New Imperative for Creating and Profiting from Technology, Harvard Business School Press, Boston.

Chesbrough, H., Vanhaverbeke, W. and West, J. (2015) New Frontiers in Open Innovation, University Press (UP), Oxford.

Cohen, W.M. and Levinthal, D.A. (1990) 'Absorptive capacity: a new perspective on learning and innovation', Administrative Science Quarterly, Vol. 35, No. 1, pp.128-152.

Coombs, R., Saviotti, P. and Walsh, V. (1987) Economics and Technical Change, Macmillan, London.

Drucker, P. (1999) Spoleczenstwo pokapitalistyczne, PWN Warszawa. 
Edquist, C. (1997) Systems of Innovation: Technologies, Institutions and Organizations, Pinter Publishers/Cassell Academic, London.

Foresight Regionalny (2013) Uniwersytet w Bialymstoku, Bialystok.

Foss, N.J., Knudsen, C. and Montgomery, C.A. (1995) 'An exploration of common ground: integrating evolutionary and strategic theories of the firm', in Montgomery, C.A. (Ed.): Resource-Based and Evolutionary Theories of the Firm: Towards a Synthesis, Kluwer Academic Publishers, Boston, Dordrecht, London.

Friedman, T.L. (2001) Lexus i drzewo oliwne, Zrozumieć globalizację, Rebis, Poznań.

Hall, P.A. and Franzese, J. (1998) 'Mixed signals: central bank independence, coordinated wage bargaining and European monetary union', International Organization, Vol. 52, No. 2, pp.505-535.

Kaufmann, A. and Todtling, F. (2001) 'Science-industry interaction in the process of innovation: the importance of boundary-crossing between systems', Research Policy, Vol. 30, No. 5, pp.791-804.

Lundvall, B.A. (2000) From the Economics of Knowledge to the Learning Economy, OECD, Paris.

Lundvall, B.A. (2010) National Systems of Innovation: Toward a Theory of Innovation and Interactive Learning, Anthem Press, London-New York-Delhi.

Malo, S. (2009) 'Growth dynamics of dedicated biotechnology firm in transition economies', Evidence from the Baltic countries and Poland, Entrepreneurship and Regional Development, Vol. 21, Nos. 5-6, pp.481-502.

Michalski, B. (2014) Competitiveness of Polish mid-tech and high-tech exports to the European Union (EU-27) in the first decade of the 21st Century', Poznan University of Economic Review, Vol. 14, No.4, pp.52-68.

Nelson, R.R. and Winter, S. (1982) An Evolutionary Theory of Economic Change, University Press (UP), Cambridge.

Nicoletti, G. and Scarpetta, S. (2003) Regulation, Productivity and Growth: OECD Evidence, Vol. 347, OECD Working Papers, Paris.

Nowiński, W. and Rialp, A. (2012) 'Drivers and strategies of international new ventures from a Central European transition economy', Journal for East European Management Studies, Vol. 18, No. 2, pp.352-373.

Som, O. (2012) Innovation without $R \& D$, Springer Gabler, Wiesbaden.

Srholec, M. and Verspagen, B. (2008) The Voyage of the Beagle in Innovation Systems Land. Explorations on Sectors, Innovation, Heterogeneity and Selection, UNU-Merit Working Paper Series \#2008-008, United Nations University, Maastricht. 